\title{
Microwave Rectifier untuk Transmisi Listrik Tanpa Kabel dengan Metode Matching Impedance
}

\author{
Wahyu Hendra Gunawan ${ }^{1 *}$, Fitri Oktafiani ${ }^{1}$ dan Deryanto Balalembang ${ }^{1}$ \\ ${ }^{I}$ Teknik Instrumentasi Elektronika Migas, Sekolah Tinggi Teknologi Migas Balikpapan \\ *wahyuhendrag@gmail.com
}

\begin{abstract}
In this modern era, the high consumption of electrical energy requires considerable resources. Resources used in this modern era include non-renewable energy and environmentally unfriendly, so it takes a new method that is environmentally friendly to meet the needs of electric energy consumption. The energy harvesting technique comes as an environmentally friendly source of energy, harvesting energy techniques utilize the resources around us without causing waste and pollution. Rectifier with matching impedance as a wireless power transmission with signal rectifier capability is an environmentally friendly method of energy harvesting technique. Rectifiers can generate electrical energy sources by utilizing electromagnetic waves as resources captured by antennas. Rectifiers are designed with application simulation process, matching impedance calculation, design printing and measurement with special measuring instrument. Rectifiers are designed and realized in the form of full-wave rectifier types. This rectifier uses a schottky diode HSMS 2860, The measurement of rectifier that uses a signal generator as a measuring device generated output of $5.08 \mathrm{~V}$ at 2.4 Ghz level $+20 \mathrm{dBm}$ and return loss $-37.70 \mathrm{dBm}$ at $2.4 \mathrm{Ghz}$ level $+5 \mathrm{~dB}$.
\end{abstract}

Keywords: Microwave, Rectifier and Matching Impedance

\begin{abstract}
Abstrak
Konsumsi energi listrik yang tinggi pada era modern ini membutuhkan sumber daya yang besar. Sumber daya yang digunakan pada era modern ini termasuk dalam non-renewable energi dan tidak ramah lingkungan, sehingga dibutuhkan sebuah metode baru yang ramah lingkungan untuk memenuhi kebutuhan konsumsi energi listrik tersebut. Teknik harvesting energy hadir sebagai metode sumber energi ramah lingkungan, teknik harvesting energy memanfaatkan sumber daya yang ada disekitar kita tanpa menyebabkan limbah dan polusi. Rectifier dengan matching impedance sebagai transmisi listrik tanpa kabel dengan kemampuan penyearah sinyal merupakan metode teknik harvesting energi yang ramah lingkungan. Rectifier dapat menghasilkan sumber energi listrik dengan memamfaatkan gelombang elektromagnetik sebagai sumber daya yang ditangkap oleh antena. Rectifier dirancang dengan proses simulasi aplikasi, perhitungan matching impedance, percetakan desain dan pengukuran dengan alat ukur khusus. Rectifier yang dirancang dan direalisasikan berupa jenis fullwave rectifier. Rectifier ini menggunakan dioda jenis schottky HSMS 2860, pada pengukuran rectifier yang menggunakan signal generator sebagai alat ukur dihasilkan output $5.08 \mathrm{~V}$ pada frekuensi $2.4 \mathrm{Ghz}$ level +20 dBm dan return loss $-37.70 \mathrm{dBm}$ pada frekuensi $2.4 \mathrm{Ghz}$ level $+5 \mathrm{~dB}$.
\end{abstract}

Kata kunci : Microwave, Rectifier dan Matching Impedance

\section{Pendahuluan}

Pada era modern ini konsumsi energi listrik menjadi hal utama yang digunakan pada kehidupan sehari hari, energi listrik dihasilkan dari proses pengolahan sumber daya seperti batu bara, minyak bumi \& gas bumi. Sumber daya minyak bumi \& gas bumi sendiri memiliki kekurangan seperti polusi dari proses pengolahannya ,ketersediannya yang semakin berkurang, dan termasuk non-renewable energy. Oleh karena itu penelitian mengenai sumber energi baru ramah lingkungan menjadi isu penting. Salah satu alternatifnya adalah 
"Microwave". Gelombang micro mudah ditemukan disekitar karena digunakan secara luas oleh banyak orang seperti aplikasi pada tower jaringan telekomunikasi, wifi, dll [1]. Energy harvesting adalah proses dimana energi yang berasal dari sumber eksternal seperti solar cell, gelombang microwave, dan gelombang elektromagnetik lain yang memancarkan sinyal. Salah satu media yang dapat digunakan untuk menangkap gelombang elektromagnetik adalah rectenna atau rectifier antenna. Rectifier atau penyearah gelombang merupakan salah satu media yang berfungsi untuk mengubah sinyal tegangan AC (Alternating Current) menjadi tegangan DC (Direct Current), sedangkan antena digunakan sebagai penangkap gelombang elektromagnetik dari ruang bebas [2].

Metode Microwave Energy Harvesting (MWEH) adalah metode yang memanfaatkan gelombang mikro yang terdapat disekitar kita. Metode MWEH biasanya diintegrasikan pada media rectenna yang mengkonversikan gelombang elektomagnetik menjadi energi listrik. Daya yang dihasilkan oleh media MWEH sangat rendah, kecuali penerima masuk dekat dengan sumber atau penerima yang sangat besar [3] [4]. Jenis rectifier full-wave adalah media yang cocok untuk metode MWEH karena gelombang Microwave yang diolah pada pada rectifier full-wave mengubah seluruh bentuk gelombang input AC menjadi polaritas konstan (positif atau negatif) dan menghasilkan tegangan output DC yang rata-rata yang lebih tinggi [5], dengan menerapkan impedance microstrip untuk perhitungan pada bagian patch rectifier [6].

\section{Desain Rectifier}

Pada desain rectifier ini diterapkan jenis rectifier full-wave atau penyearah gelombang penuh Gambar 1. Circuit
Diagram rectifier full-wave. Umumnya untuk jenis rectifier full-wave digunakan 2 sampai dengan 4 dioda, berbeda dengan jenis rectifier half-wave yang hanya menggunakan 1 dioda, untuk karakteristik jenis full-wave lebih baik dari jenis halfwave karena pada saat posisi high state maupun low state keadaan output jenis full-wave tetap menghasilkan tegangan, dalam rangkaian jenis full-wave digunakan kapasitor dengan ukuran $\mathrm{C}_{1}=120 \mathrm{pF} \mathrm{C_{2 }}=$ $120 \mathrm{nF}$ sebagai filter yang berfungsi mengurangi ripple atau riak (lonjakan arus) pada saat proses sebelum disearahkanya sinyal AC yang dengan diode pada rectifier.

Dalam rangkaian rectifier full-wave ini digunakan beberapa desain patch antara sisi kanan dan kiri transmission line yang memiliki ukuran berbeda-beda terkecuali untuk desain patch yang memiliki throughhole, memiliki ukuran yang sama bisa dilihat pada Gambar 2. Desain rectifier diterapkannya through-hole pada desain untuk sebagai penghubung antara patch bagian atas dan ground [7]. Dalam desain ini diterapkan impedance matching sebagai perhitungan pada patch yang berfungsi sebagai impedansi gabungan antara patch pada rangkaian [8]. Dan pada desain ini digunakan dioda jenis Schottky HSMS 2860 single series karena memiliki ketelitian yang tinggi untuk penyearah arus dengan nilai $1 \mathrm{~mA}$.

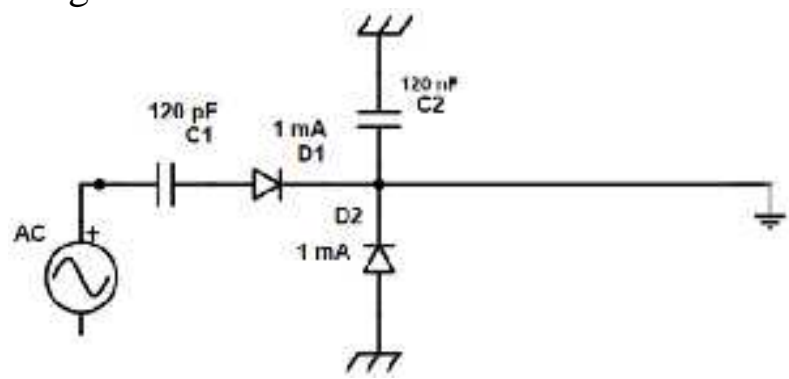

Gambar 1. Circuit Diagram rectifier full-wave 
$W$



Gambar 2. Desain rectifier

Tabel 1. Parameters Rectifier

\begin{tabular}{|c|c|c|c|}
\hline Parametes & $\begin{array}{l}\text { Value } \\
\text { (mm) }\end{array}$ & Parameters & $\begin{array}{l}\text { Value } \\
\text { (mm) }\end{array}$ \\
\hline $\bar{W}$ & 40 & $L$ & 80 \\
\hline$W_{I}$ & 3 & $L_{1}$ & 1.3 \\
\hline$W_{2}$ & 5.4 & $L_{2}$ & 2.2 \\
\hline$W_{3}$ & 14.1 & $L_{3}$ & 1.9 \\
\hline$T H_{I}$ & 1 & $\mathrm{TH}_{2}$ & 1 \\
\hline$D_{1}$ & 1 & $D_{3}$ & 1 \\
\hline$D_{2}$ & 1 & $D_{4}$ & 1 \\
\hline$W_{4}$ & 19.2 & $L_{4}$ & 8.1 \\
\hline$W_{5}$ & 18.4 & $L_{5}$ & 6.5 \\
\hline$W_{6}$ & 13.6 & $L_{6}$ & 4.9 \\
\hline$W_{7}$ & 8.5 & $\boldsymbol{L}_{7}$ & 2.2 \\
\hline$W_{8}$ & 14.1 & $L_{8}$ & 1.5 \\
\hline$W_{9}$ & 0.7 & $T L$ & 80 \\
\hline
\end{tabular}

\section{Hasil dan Pembahasan}

Pada pengukuran rectifier digunakan 2 alat ukur yaitu signal generator sebagai sumber input dan multimeter digital untuk mengukur tegangan pada output. Dengan 3 variasi ouput yaitu tanpa resistor, resistor 1 $\mathrm{K}$ dan resistor $2 \mathrm{~K}$. Pada Gambar 3 . Tegangan ouput rectifier tanpa resistor dapat diketahui untuk frekuensi $0.5 \mathrm{Ghz}$ s/d 1.5 Ghz dengan level $+5 \mathrm{dBm}$ sampai dengan $+15 \mathrm{dBm}$ dihasilkan output 0.001 $\mathrm{V}$ hingga $0.245 \mathrm{~V}$. Sedangkan pada frekuensi $2.4 \mathrm{Ghz}$ dan $3 \mathrm{Ghz}$ level +20 $\mathrm{dBm}$ mengalami peningkatan signifikan dengan output $5.08 \mathrm{~V}$ dan $5.19 \mathrm{~V}$, kurangnya output pada frekuensi $0.5 \mathrm{Ghz}$ sampai dengan 1.5 Ghz bisa saja disebabkan karena tidak adanya hambatan pada output rectifier.

Berbeda halnya dengan Gambar 4. Tegangan ouput rectifier dengan resistor 1 $\mathrm{K}$ dapat dilihat pada frekuensi $1 \mathrm{Ghz}$ level $+20 \mathrm{dBm}$ dan 1.5 Ghz level +20 $\mathrm{dBm}$ di hasil kan output $0.339 \mathrm{~V}$ dan 0.492 $\mathrm{V}$, hanya mengalami peningkatan sebesar 0.153 V. Sedangkan pada frekuensi $2 \mathrm{Ghz}$ dan 2.4 Ghz level $+20 \mathrm{dBm}$ mengalami peningkatan signifikan dengan output $2.142 \mathrm{~V}$ dan $3.825 \mathrm{~V}$. Tapi pada frekuensi $0.5 \mathrm{Ghz}$ level $+5 \mathrm{dBm}$ sampai dengan +15 $\mathrm{dBm}, 1 \mathrm{Ghz}$ level $+5 \mathrm{dBm}$ sampai dengan $+10 \mathrm{dBm}, 1.5 \mathrm{Ghz}$ level $+5 \mathrm{dBm}$ s/d +15 $\mathrm{dBm}$, dan $3 \mathrm{Ghz}$ level $+5 \mathrm{dBm} \mathrm{s} / \mathrm{d}+20$ $\mathrm{dBm}$ tidak dihasilkan output, bisa jadi di sebabkan karena dengan hambatan $1 \mathrm{~K}$ untuk frekeunsi dan level pada output rectifier terlalu besar. Berbeda halnya pada Gambar 5. Tegangan ouput rectifier dengan resistor $2 \mathrm{~K}$ dapat diketahui untuk frekuensi $0.5 \mathrm{Ghz}$ level $+5 \mathrm{dBm}$ sampai dengan $+15 \mathrm{dBm}, 1 \mathrm{Ghz}$ level +5 $\mathrm{dBm}$ sampai dengan $+10 \mathrm{dBm}, 1.5 \mathrm{Ghz}$ level $+5 \mathrm{dBm}$ sampai dengan $+15 \mathrm{dBm}$ tidak dihasil kan output, bisa jadi di sebabkan karena hambatan $2 \mathrm{~K}$ untuk 
frekeunsi dan level pada output rectifier terlalu besar untuk frekuensi tersebut. Sedangkan pada frekuensi $2.4 \mathrm{Ghz}$ dan 3 Ghz dengan level $+15 \mathrm{dBm}$ dan $+20 \mathrm{dBm}$ mengalami peningkatan signifikan dengan output $2.302 \mathrm{~V}, 2.744 \mathrm{~V}, 4.08 \mathrm{~V}$ dan 3.932 V.

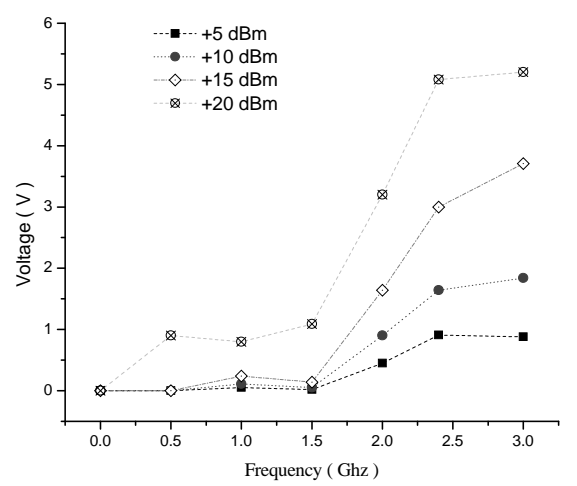

Gambar 3. Tegangan Ouput Rectifier tanpa Resistor



Gambar 4. Tegangan Ouput Rectifier dengan Resistor $1 \mathrm{~K}$

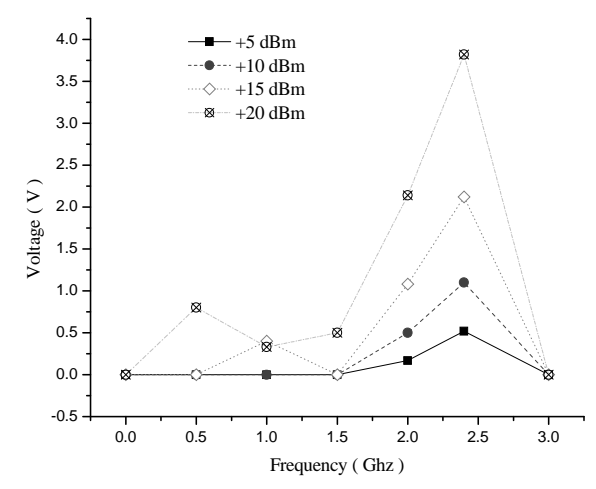

Gambar 5. Tegangan Ouput Rectifier dengan Resistor $2 \mathrm{~K}$

\section{Kesimpulan}

Pada pengukuran rectifier ini difokuskan pada frekuensi $2.4 \mathrm{Ghz}$, hasil tertinggi pada pengukuran tanpa beban resistor yaitu $5.08 \mathrm{~V}$

\section{Daftar Pustaka}

[1] Deep Patel, Rohan Mehta, Rhythm Patwa, Sahil Thapar, and Shivani Chopra, "RF Energy Harvesting," p. 4, 2014.

[2] Hamka Ikhlasul Amal NZ, Arfianto Fahmi, and Yuyu Wahyu, "Perancangan dan Realisasi Sistem RF Energy Harvesting pada Frekuensi UHF," p. 8, 2016.

[3] P. Dziurdzia, "Modelling and simulation of thermoelectric energy harvesting processes," 2011.

[4] Vlad Marian, Bruno Allard, Christian Vollaire, and Christian Vollaire, "Strategy for Microwave Energy Harvesting From Ambient Field or a Feeding Source," p. 10, 2012.

[5] Williams B. W., "Power electronics," p. 380, 1992.

[6] Yusuf Abubakar Maiwada, "Impedance Matching Optimization: A Case of RF Energy Harvesting," p. 4, 2016.

[7] Ta Chien Tecnology, "Silver Through Hole Double-Sided Printed Circuit Boards," p. 1, 2012.

[8] Datta Kundu Parna Kundu, Acharjee Juin, and Mandal Kaushik, "Design of an Efficient Rectifier Circuit for RF Energy Harvesting System,” p. 4, 2017. 